\title{
USING MCDA METHODS THOR IN AN APPLICATION FOR OUTRANKING THE BALLAST WATER MANAGEMENT OPTIONS
}

\author{
Carlos Francisco Simões Gomes \\ CASNAV (Brazilian Naval Center of System Analysis) \\ Rio de Janeiro - RJ \\ simoes@casnav.mar.mil.br; cfssg1@bol.com.br
}

Recebido em 09/2003; aceito em 02/2005 após 2 revisões Received September 2003; accepted February 2005 after 2 revisions

\begin{abstract}
The Multicriteria Analysis Methodology has been developed in order to support and guide decisionmakers in the evaluation and selection of alternatives/solutions. In this case, it is used to compare alternatives for the management ballast water (BW) exchange systems and treatment methods.
\end{abstract}

Keywords: ballast water problem; multicriteria; management.

\section{Resumo}

O Apoio Multicritério à Decisão (AMD) desenvolve metodologias que ajudam o tomador ou agente de decisão a avaliar e selecionar alternativas. Este trabalho apresenta uma aplicação real do AMD em uma situação de ordenação de alternativas para o gerenciamento do problema de água de lastro.

Palavras-chave: problema da água de lastro; multicritério; gerenciamento. 


\section{Introduction}

Each individual is endowed with internal information processing and problem-solving capacity, which varies with time. The human hierarchy of values is dependent on of the number of state variables, the human physiological and psychological conditions, social situation, and self-suggested goals.

When a set of Decision-Makers (DM) and a set of objectives exist, the multiobjective decision analysis problem needs to obey three parameters (Bodily, 1978):

- Multiperiod - the consequences of a decision are spread over $N$ time periods, with $x_{t}$ being the consequence $x$ in time period $t$. For example, $x_{t}$ may be the cash flow in year $t$ from an investment opportunity. The Stability is a Multiperiod interpretation.

- Multiperson - the consequences are spread over $M$ individuals. For example, $x_{i}$ may be the investor $i$ share of the partnership profit. Equality is a Multiperson interpretation. Decision Making problems that we encounter in the real world are often associated with several individuals or groups whose interests and/or preferences attitudes are different. In those situations, individual preferences should be aggregated.

- Multivariable - the consequences are spread over several parts of an organization, over several economic activities, or over several categories of a problem. For example, $x_{n}$ may be the market share of a product. Balance is a multivariable interpretation.

\subsection{Decision Maker values}

Answering some questions may help the DM to identify his own values:

- What are the feasible alternatives for the decision problem? Can we expand the feasible set?

- What are the goal functions?

- What is the set of criteria?

- What are the consequences of the alternatives?

- How do we reduce uncertantainty and risk? (Ignoring uncertainties results in a severe oversimplification. Uncertainties create an environment in which risk attitudes play an important role)

- How can we rank the preferences?

- Do we have contingence plans for undesirable consequences?

- Who are the decision actors?

- Who are the people who may change the outcomes of the decision?

- What are the reliable external information sources?

- How do we obtain accurate information from them (the DM)?

- Are there conflicting interests?

Possible individual goals are (Vind, 2000; Varlan, 1999):

- Self survival and security, physiological health (right blood pressure, body temperature and balance of biochemical states), safety and freedom from dangers; right level and quality of air, water, food, heat, clothes, shelter and mobility, acquisition of money and other economic goods. 
- Perpetuation of the species: sexual activities, giving birth to the next generation, family love, health and welfare.

- Feeling of self-importance: self-respect ans. self-esteem, esteem and respect from others, power and dominance, recognition, prestige, achievement, creativity, superiority, giving and accepting sympathy and protectiveness.

- Social approval; esteem and respect from others, affiliation, friendship, conformity with a desired group, giving and accepting sympathy and protectiveness; conformity with group ideology, beliefs, attitudes and behaviours.

- Sensed gratification: sexual, visual, smell, taste, tactile etc.

- Cognitive consistency and curiosity: consistency in thought and opinions, exploring ans. acquiring knowledge, truth and religion.

- Self-actualization: the ability to accept and depend on the self, to rely on one's own standard, to cease identifying with others, to aspire to the "ego-ideal'.

Observation: Vind (2000) proved that pre-order on a set of functions could be represented by the expected value of a utility function. Knoblauch (2000) prove the non-existence of representation via lexicographic orders for all preference relations.

\subsection{Group values}

In a group of DM we have:

- The degree of importance of each individual member of the group;

- The values for the attributes of the alternatives for each member of the group; and

- The coefficient vector of the additive utility function of each individual.

The final goal for the group decision making process is to aggregate mutually conflicting individual preferences into a group preferences and to decide an alternative to be chosen by the group. The context of group discussion includes Negotiation (Gomes et al., 1996, 1997, 1998, 1999a), which must take into account the following questions:

- Is the habitual domain of one group able to absorb the habitual domains of another group?

- What are the common interests and the conflicting interests?

- Can we emphasize the common goals to encourage co-operation and reduce competition?

- Can we introduce new players, or change the rules, or can we influence the players in order to change the situation in a way favorable to us?

- Can we form coalition?

Karni and Safra propose by Harsanyi's Theory (Karni \& Safra, 2000; Vind, 2000) that exist two preference relations, one representing the individual choice behaviour among socialalternatives lotteries and the second representing moral value judgement. Haranyi (2000) assumes that the two preference relations satisfy the axioms of expected utility theory. Karni \& Safra (2000) proved that the impartial observer's preference relation may be viewed as a fair and reasonable procedure of aggregating individual preferences into a social preference relationship. 


\section{The Multicriteria Decision Making Aiding (MCDA) Methodology}

One of the greatest difficulties that decision-makers face is to identify feasible solutions for problems and to prioritize the selected ones. This process happens under the influence of quantitative and qualitative approaches, which do often come in conflict with each other. The classification of the qualitative approaches is also influenced by the fact that each decisionmakers group forces its own criteria and values.

The literature about MCDA is vast and can be found in, for example, "Vincke, Philippe, 1992, Multicriteria Decision-Aid. Ed. John Wiley \& Sons, Inc", and "Roy, Bernard, Bouysson, Denis, 1993, Aide Multiple a la Decision: Methods et cas. Ed. Economica, France".

MCDA methods are valuables tools in handling such inter personal conflicts where the aim is to achieve consensus between the group members or at least reduce the amount of conflict among individual participants (Matsatsimis \& Samaras, 2001).

The Multicriteria (Gomes et al., 2002c) methodology accepts the following basic assumptions:

- Complexity of the decision-making process, which involves many parties that define the relevant aspects of such process;

- Inherent subjectivity of each party's opinion (value judgement);

- Acknowledgement of the limits of objectivity and due consideration of the subjectivity; and

- Inaccuracy due to the fact that the problem has not been clearly defined.

MCDA provides a variety of techniques to address sorting problems. The development of sorting models through MCDA techniques often requires the decision maker to define specific information on the parameters of the developed model (Matsatsimis \& Samaras, 2001).

The obvious obstacle when multiple persons are involved in a joint decision problem is the fact that each individual has his/her own perception of the problem based on the decision outcome (Zopounidis \& Doumpos, 2003).

MCDA methods may be a useful tool to deal with such interpersonal conflicts where the aim is to achieve consensus between the group members or at least attempt to reduce that amount of conflict by concessions. A problem arises when aggregating the preferences of a group of individuals to construct a joint decision model (Matsatsimis \& Samaras, 2001).

An understanding of the relationship between current decisions and future outcomes is crucial for the analysis of economic growth, the role for saving and investment, the properties of asset markets, and other important topics (Noussair \& Matheny, 2000).

Considering, for example, the investment decision in a global economic world, with many influences changing the environment, we can assume that:

- Decisions are nonrepetitive;

- The criteria for evaluating the investment alternative are subjective, and they can be defined by the DM; and

- The alternatives can be evaluated by criteria, using a scale (Torgerson, 1985); the DM must choose the best scale for each criteria/alternative. 
Economic constraints often push us to make difficult choices within a limited budget. This choice is rarely unique (Varlan \& Paillier, 1999). There is no one DM but several decision actors, who can be affected or not by the decision. Multicriteria Analysis is adapted for selection of the optima strategies because:

- The actors have a set of tools which permit modeling the decision process;

- Models utilizing probabilities of success, risk, measurements of benefits or utility are helpful to guide the manager, but they only work for a limited number of cases, when the distributions are know; and

- The high number of parameters and different possibilities for the weights.

We can use many MCDA methods in economics or market, for example:

- Outranking methods: that use concordance indexes to measure the intensity of the agreement between that average opinions of the group of decision makers, and the discordance index which measures the intensity of the disagreement between the average opinions of the group of decision makers; and

- Either Utility Theory or Perspective Theory: incompleteness of market may cause price fluctuations in financial markets (Calvet, 2001); or Project finance or project financing involves performing a set of security arrangements to reduce risk in large infra-structural investments (Ballestero, 2000).

Next, we are going to use the MCDA technique in a problem of the real world. The following section will describe the use of the MCDA as a toll to choose the best ballast water (BW) treatment system.

\section{Example Application of the MCDA Methodology}

\subsection{BW treatment options - the problem}

The introduction of invasive marine species into new environments by ships' ballast water, attached to ships' hulls and via other vectors has been identified as one of the four greatest threats to the world's oceans. The other three are land-based sources of marine pollution, overexploitation of living marine resources and physical alteration/destruction of marine habitat. Shipping moves over $80 \%$ of the world's commodities and transfers approximately 3 to 5 billion tons of ballast water internationally each year. A similar volume may also be transferred domestically within countries and regions each year. Ballast water is absolutely essential to the safe and efficient operation of modern merchant ships, providing balance and stability to unloaded ships. However, it may also pose a serious ecological, economic and health threat.

Observation: Ballast is any material used to weight and/or balance an object. One example is the sandbags carried on conventional hot-air balloons, which can be discarded to lighten the balloon's load, allowing it to ascend. Ballast water is therefore water carried by ships to ensure stability, trim and structural integrity. Ships have carried solid ballast, in the form of rocks, sand or metal, for thousands of years. In modern times, ships use water as ballast. (http: //globallast.imo.org/index.asp?page=problem.htm\&menu=true). 


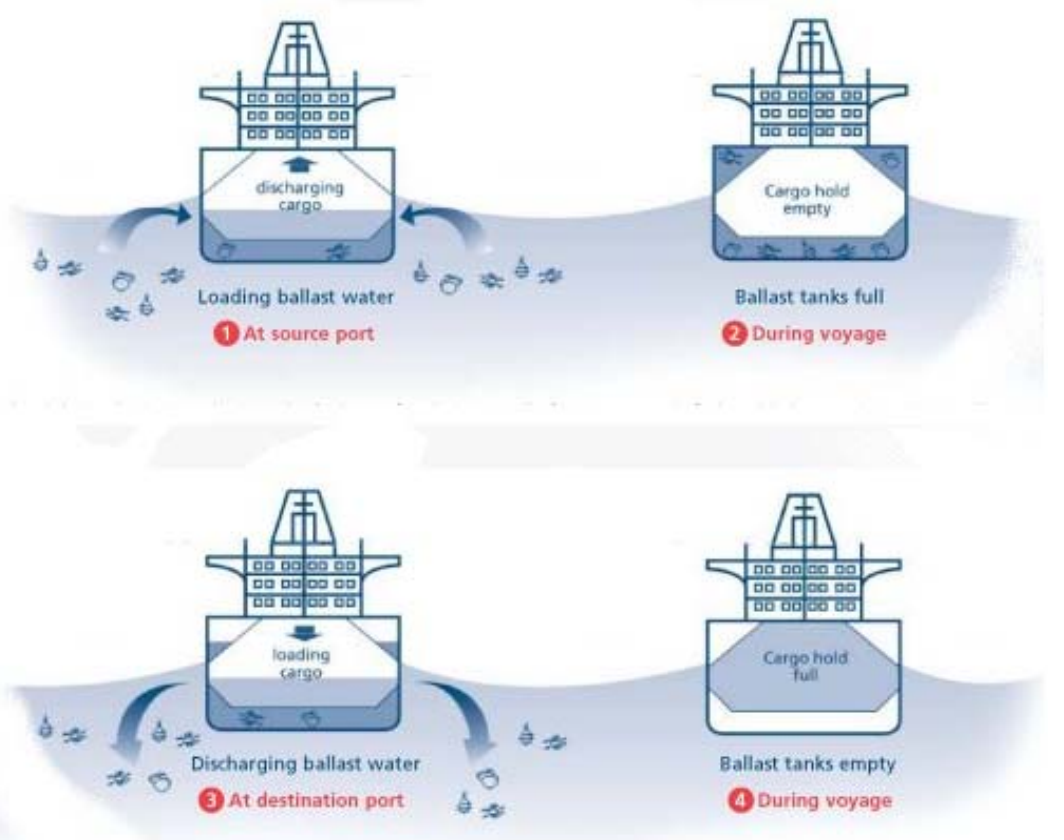

Figure 1 - Ballast water cycle.

(http://globallast.imo.org/index.asp?page=problem.htm\&menu=true)

It is estimated that at least 7,000 different species are being carried in ships' ballast tanks around the world (Figure 1). The vast majority of marine species carried in ballast water do not survive the journey, as the ballasting and deballasting cycle and the environment inside ballast tanks can be quite hostile to organism survival. Even for those that do survive a voyage and are discharged, the chances of surviving in the new environmental conditions, including predation by and/or competition from native species, are further reduced. However, when all factors are favourable, an introduced species by survive to establish a reproductive population in the host environment, it may even become invasive, out-competing native species and multiplying into pest proportions. (http://globallast.imo.org/index.asp?page=problem.htm\&menu=true).

As the situation becomes more and more serious, the International Maritime Organization (IMO) has sponsored international meetings to found out courses of action to meet this challenge, where the subject is discussed by the IMO Member States.

As a result, whole ecosystems are being changed. In the USA, the European Zebra Mussel Dreissena polymorpha has infested over $40 \%$ of internal waterways and may have required between US\$ 750 million and US\$ 1 billion in expenditure on control measures between 1989 and 2000. In southern Australia, the Asian kelp Undaria pinnatifida is invading new areas rapidly, displacing the native seabed communities. In the Black Sea, the filterfeeding North American jellyfish Mnemiopsis leidyi has on occasion reached densities of $1 \mathrm{~kg}$ of biomass per $\mathrm{m} 2$. It has depleted native plankton stocks to such an extent that it has 
contributed to the collapse of entire Black Sea commercial fisheries. In several countries, introduced, microscopic, 'red-tide' algae (toxic dinoflagellates) have been absorbed by filter-feeding shellfish, such as oysters. When eaten by humans, these contaminated shellfish can cause paralysis and even death. The list goes on, hundreds of examples of major ecological, economic and human health impacts across the globe. It is even feared that diseases such as cholera might be able to be transported in ballast water. (http://globallast.imo.org/index.asp?page=problem.htm\&menu=true).

Invasive marine species are one of the four greatest threats to the world's oceans. Unlike other forms of marine pollution, such as oil spills, where ameliorative action can be taken and from which the environment will eventually recover, the impacts of invasive marine species are most often irreversible (International Maritime Organization - IMO http://www.imo.org/home.asp).

\begin{tabular}{|c|c|c|c|c|c|}
\hline \multirow[b]{2}{*}{ VESSEL TYPE } & \multirow[b]{2}{*}{ DWT } & \multicolumn{4}{|c|}{ BALLAST CONDITION } \\
\hline & & $\begin{array}{l}\text { NORMAL } \\
\text { (tonnes) }\end{array}$ & $\%$ of DWT & $\begin{array}{r}\text { HEAVY } \\
\text { (tonnes) }\end{array}$ & \% of DWT \\
\hline Bulk carrier & 250,000 & 75,000 & 30 & 113,000 & 45 \\
\hline Bulk carrier & 150,000 & 45,000 & 30 & 67,000 & 45 \\
\hline Bulk carrier & 70,000 & 25,000 & 36 & 40,000 & 57 \\
\hline Bulk carrier & 35,000 & 10,000 & 30 & 17,000 & 49 \\
\hline Tanker & 100,000 & 40,000 & 40 & 45,000 & 45 \\
\hline Tanker & 40,000 & 12,000 & 30 & 15,000 & 38 \\
\hline Container & 40,000 & 12,000 & 30 & 15,000 & 38 \\
\hline Container & 15,000 & 5,000 & 30 & $n / a$ & \\
\hline General cargo & 17,000 & 6,000 & 35 & $\mathrm{n} / \mathrm{a}$ & \\
\hline General cargo & 8,000 & 3,000 & 38 & $\mathrm{n} / \mathrm{a}$ & \\
\hline Passenger/RORO & 3,000 & 1,000 & 33 & $n / a$ & \\
\hline
\end{tabular}

Figure 2 - The distribution of BW within a vessel will depend on the design criteria, size and strength of the vessel.

The source for Figure 2 is the Australian Quarantine \& Inspection Service 1993, Ballast Water Management, Ballast Water Research Series Report No. 4 AGPS Canberra.

\subsection{MCDA in the BW problem}

The system proposed by this paper to use on IMO is based on the algorithm THOR [see Annex I] (Gomes, 1999b), which has been the subject of a presentation given at the Symposium of the International Federation of Operational Research Societies (IFORS), 2002, in Edinburgh from 8 to 13 of July 2002 and 12th. Mini-Euro Conference, Brussels, 2002 (Gomes et al., 2000, 2001, 2002a, 2002b, 2003). 
This paper submits a methodology of outranking BW treatment options. A result of the application of this methodology will be used in order to obtain the indication, consensually, of the best treatment system.

When applied to group's decisions, the MCDA allows individual preferences to be combined in such way that it results in a group decision. The THOR system, which uses the MCDA, has a module that allows the group to reach a decision through the exchange of views of the group members, from which the negotiation (Haranyi, 2000) around the acceptable proposals starts (i.e. around the preliminary accepted BW treatment and exchange methods).

The process used:

Step 1: identify in all proposals submitted by IMO Member States the relevant criteria;

Step 2: submit this set of criteria to IMO Member States;

Step 3: obtain the consensus about the criteria set;

Step 4: identify the alternatives that solve the problem;

Step 5: submit the alternatives to IMO Member States;

Step 6: use the THOR module to help the IMO Member States to identify the importance (weight) to criteria;

Step 7: alternative ordination.

The Multicriteria aid helps the decision making process by incorporating the value judgement of the IMO Member States taking into account their preferences and interpreting the procedure as a learning process. Thus, it helps to select the best ballast water exchange and treatment methods.

In order to apply this methodology to the case under consideration, relevant factors have been identified. They are:

- Practicability;

- Biological effectiveness (including pathogens);

- Cost/benefits;

- Time frame within which the standards could be practically implemented;

- Environmental impact of the process' sub-products.

\subsubsection{Criteria application}

The detailed criteria, referring to the relevant factors identified, for quantitative measuring in association with a nominal scale or description, are reproduced in paragraph 3.2.2 Questions. They are numbered from 1 to 26 [Table I - Criteria and Management Alternatives and Figure 3]. Each criteria presented shall be analyzed and represented using quantitative measuring. It can be done by assign a value in a nominal scale, by a value attributed to a yes or no answer, or by an interval scale or ration scale.

For this study the following was adopted:

(a) Restriction (veto criterion) - the system to be incorporated or selected shall not present any restrictions unacceptable.

(b) All criteria have the same weight (during the presentation of this article by Brazilian Delegation at IMO meeting, the IMO members did not achieve consensus about the weights). 


\subsubsection{Questions}

a) Practicability

a.1) Quantitative criteria

1 - what ballast flow rate range is the system applicable? $\left(\mathrm{m}^{3} /\right.$ hour) (specify the minimum and maximum flow rate)

2 - what is the ship tonnage that the system can be applied to? (DWT) (specify the minimum and maximum tonnage)

3 - what is the additional workload on board? (man/hours)

4 - what is the highest sea state (in the Beaufort wind scale) on which the system can operate?

5 - what is the increase in tank's sediment caused by the system? (specify percentage)

a.2) Questions that need to be answered by a nominal scale, subject to association to a numerical scale of intervals or by a yes/no answer

6 - does the system present any risks to the ship's crew safety or to the crew? ( -3 , high risk; -2 , medium risk; -1 , low risk; 0 , no risk)

7 - does the system affect the tanks' corrosion rate? ( -2 , increases the rate; -1 , does not increase the rate; 0 , reduces the rate)

8 - does the system dispense with the need to keep chemical products on board? (Yes or No)

9 - can the system be used in short voyages (up to $12 \mathrm{~h}$ )? (Yes or No)

10 - can the system be operated without complete re-circulation of the ballast water? (Yes or No)

11 - is the system unaffected by incrustation that could lead to a drop in pressure and/or to a reduction in the flow rate? (Yes or No)

12 - is the system being applicable to existing ships? (Yes or No)

13 - are the ship's other functions independent from the system's operation? (Yes or No)

\section{a.3) Questions that require detailed answers}

14 - does the system present any occupational hazard to the operator? Describe and quantify. ( -3 , high; -2 , medium; -1 , low; 0 , no hazard)

b) Biological effectiveness (including pathogens)

\section{b.1) Quantitative Criteria}

15 - how effective is the system in relation to the removal, elimination and inactivation/neutralization of aquatic organisms, apart from pathogens (according to the various taxonomic groups)? (quantify in terms of percentage, size and/or concentration of organisms)

16 - same as 15 for pathogens. 
b.2) Questions for which the answers should be either Yes or No

17 - does the system eliminate cysts?

18 - does the system allow the elimination of organisms when the water enters the tank?

19 - is the system adequate for the elimination of all species or life stages that may present a hazard to the environment?

c) Cost-benefits

c.1) Quantitative criteria

20 - what is the purchase cost? (US\$)

21 - what is the cost of installation? (US\$)

22 - what is the operational cost? (US\$/ton)

23 - what is the cost variation per ship size? (US\$/ton)

24 - what is the increase of fuel or oil consumption that is introduced by the use of this system on board? (percentage)

d) Time frame within which the standards could be practically implemented

d.1) Quantitative criteria

25 - within which time frame could the standards be practically implemented? (months)

e) Influence of the system's sub-products on the environment

e.1) Question for which the answer should be either Yes or No

26 - is the system free from generating sub-products that can have an impact on the environment?

Observation: Undesirable outcomes are taken with negative values as well as those that have a negative impact with higher absolute values. According to that:

- In the criteria $3,5,20-24$ and 25 , negative values are assign for the lowest desirable feature;

- In the criteria 8 to $13,17,18,19$ and 26, where the answers should be either "Yes" or "No", a value of 1 was assigned to a "Yes" answer (desirable) and a value of 0 to a "No" answer (undesirable);

- In the criteria 6, 7 and 14 , verbal (or nominal) scales associated to a numerical scale have been created for test purposes.

\subsubsection{Example of the MCDA application}

Table I presents an example utilization of this method using three management methods. It is difficult, in the following table, to find out the best management method. This problem becomes even more complicated if we consider that there are several ballast water treatment methods currently being discussed at IMO and not just the three ones used as example. 
Table I - Criteria and management alternatives.

\begin{tabular}{|c|c|c|c|}
\hline \multirow{2}{*}{ Criteria } & \multicolumn{3}{|c|}{ Alternatives } \\
\hline & Management Method 1 & Management Method 2 & Management Method 3 \\
\hline 1 & $\begin{array}{l}\text { Maximum 15,000 m³/hour } \\
\text { Minimum } 100 \mathrm{~m}^{3} / \mathrm{hour}\end{array}$ & $\begin{array}{l}\text { Maximum } 14,000 \mathrm{~m}^{3} / \text { hour } \\
\text { Minimum } 200 \mathrm{~m}^{3} / \text { hour }\end{array}$ & $\begin{array}{l}\text { Maximum } 13,000 \mathrm{~m}^{3} / \text { hour } \\
\text { Minimum } 300 \mathrm{~m}^{3} / \text { hour }\end{array}$ \\
\hline 2 & $\begin{array}{c}\text { Maximum 450,000 DWT } \\
\text { Minimum 450 DWT }\end{array}$ & $\begin{array}{c}\text { Maximum 350,000 DWT } \\
\text { Minimum 350 DWT }\end{array}$ & $\begin{array}{c}\text { Maximum 250,000 DWT } \\
\text { Minimum 450 DWT }\end{array}$ \\
\hline 3 & $90 \mathrm{man} / \mathrm{hours}$ & $80 \mathrm{man} / \mathrm{hours}$ & 90 man/hours \\
\hline 4 & 7 & 8 & 10 \\
\hline 5 & $10 \%$ & $12 \%$ & $5 \%$ \\
\hline 6 & -1 & -2 & -3 \\
\hline 7 & -2 & -1 & 0 \\
\hline 8 & 1 & 1 & 0 \\
\hline 9 & 1 & 1 & 0 \\
\hline 10 & 1 & 1 & 0 \\
\hline 11 & 0 & 1 & 1 \\
\hline 12 & 0 & 1 & 1 \\
\hline 13 & 0 & 0 & 1 \\
\hline 14 & 0 & -1 & -2 \\
\hline 15 & $93 \%$ & $92 \%$ & $90 \%$ \\
\hline 16 & $90 \%$ & $88 \%$ & $91 \%$ \\
\hline 17 & 1 & 0 & 1 \\
\hline 18 & 1 & 0 & 0 \\
\hline 19 & 0 & 1 & 1 \\
\hline 20 & US\$ $200,000.00$ & US\$ $210,000.00$ & US\$220,000.00 \\
\hline 21 & US\$ $10,000.00$ & US\$ $21,000.00$ & US\$ $1,000.00$ \\
\hline 22 & $0.02 \mathrm{US} \$ /$ ton & $0.03 \mathrm{US} \$ /$ ton & $0.04 \mathrm{US} \$ /$ ton \\
\hline 23 & US\$ 9 & US\$ 8 & US\$ 6 \\
\hline 24 & $3 \%$ & $8 \%$ & $1 \%$ \\
\hline 25 & 6 months & 8 months & 9 months \\
\hline 26 & 0 & 1 & 0 \\
\hline
\end{tabular}

\subsubsection{Results using the software THOR}

It is possible to outrank the worst management methods and identify the best ones applying the THOR [see Annex I] methodology to the data from the Table I, as shown in the Figure 3 and Figure 4 further shown.

The outranking relations (S1, S2 and S3) are described in Annex I.

Observation: the alternatives are evaluated in criteria 1, 2, 3, 20, 21, 22, 23 and 25 by ration scale; interval scale, criteria 5, 15 and 16, the other criteria use nominal scale associated with a interval scale (Torgerson, 1985). 


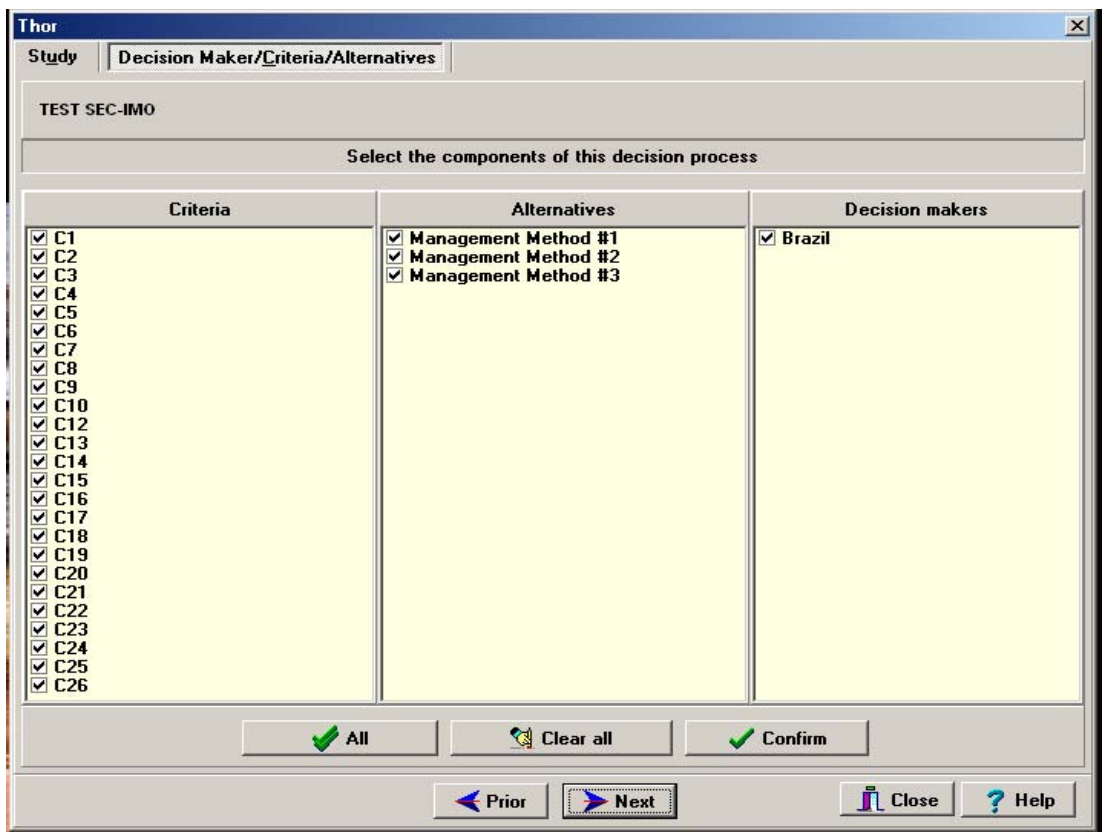

Figure 3 - Criteria and alternatives.

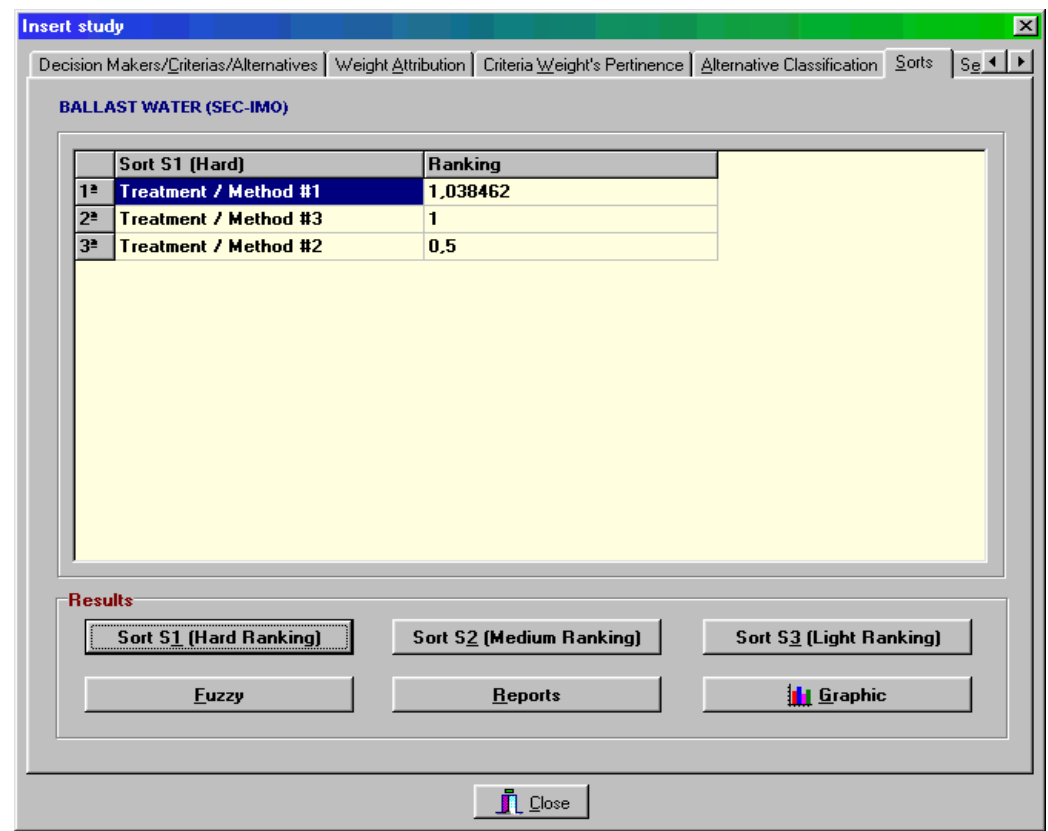

Figure 4 - THOR results.

Using the software THOR (Figure 4), it can be seen that the Management Method 1 is the best method, slightly better than Management Method 3. 


\section{Conclusions and Recommendations}

In order to apply this methodology to the problem of ballast water, the IMO Member States should take the following steps:

a) Define which criteria will be used to evaluate the management methods. The Committee will, then, decide on the value to be assigned to each criterion and will also define the initial restriction (veto). (Brazilian Delegation suggests, as a starting point for the discussions on the restriction, that the docking time should not exceed $10 \%$ of the time allowed for before the introduction of the system. The same time limit should be observed with regards to the increase in the time of ship's construction. Please note: any system presented for evaluation should have been tested on board, and laboratory tests should not be accepted for this purpose);

b) Stipulate the deadlines for disputing the outcome of the evaluation of the management methods (the outcome shall be disputed by means of a new evaluation carried out by the disputing party);

c) Establish the relative value to be assigned to each evaluation criteria and apply the data obtained through the evaluation of each treatment method to the THOR system and outrank the worst methods.

Based in the above steps IMO could select the best course of actions based on scientific methodology avoiding take decisions based on misleading individual preferences expressed by voting.

\section{References}

(1) Ballestero, E. (2000). Project Finance: a Multicriteria approach to arbitration. Journal of the Operational Research Society, 51, 183-197.

(2) Bodily, S.E. (1978). Police sector design incorporating preferences of interest groups for equality and efficiency. Management Science, 24(12).

(3) Calvet, L.E. (2001). Inclopete Markets and Volatility. Journal of Economic Theory, 98, 295-338.

(4) Gomes, C.F.S. \& Gomes, L.F.A.M. (1996). Aplicação da Teoria dos Conjuntos Aproximativos à Modelagem Analítica de Apoio à Negociação. In: Anais do VIII CLAIO - Latin-Iberian-American Congress on Operations Research and Systems Engineering e XXVIII Simpósio Brasileiro de Pesquisa Operacional, v. II, 866-871, Rio de Janeiro.

(5) Gomes, C.F.S. \& Gomes, L.F.A.M. \& Moreira, A.M.M. (1997). Modelos Analíticos para a Negociação. In: Anais do XXIX Simpósio Brasileiro de Pesquisa Operacional, v.1, 161-161, Salvador.

(6) Gomes, C.F.S. \& Gomes, L.F.A.M. \& Moreira, A.M.M. (1998). Modelos Analíticos para Negociação. Revista Pesquisa Naval, 11, 151-157.

(7) Gomes, C.F.S. \& Gomes, L.F.A.M. (1999a). Uma Aplicação de Conjuntos Aproximativos ao Apoio Multicritério à Negociação. Revista Pesquisa Naval, 12, 263-270. 
(8) Gomes, C.F.S. (1999b). THOR - Um Algoritmo Híbrido de Apoio Multicritério à Decisão para Processos Decisórios com Alternativas Discretas. Tese de Doutorado, Engenharia de Produção, COPPE-UFRJ.

(9) Gomes, C.F.S.; Gomes, L.F.A.M. \& Valle, R.A.B. (2000). Aplicação do THOR em um Processo de Seleção de Pessoal. XXXII Simpósio Brasileiro de Pesquisa Operacional, Viçosa.

(10) Gomes, C.F.S.; Gomes, L.F.A.M. \& Valle, R.A.B. (2001). Nova Proposta de Aplicação do Apoio Multicritério à Decisão (Algoritmo THOR) em Ordenação de Alternativas. XI Encontro Nacional dos Estudantes de Engenharia de Produção - ENEGEP-2001.

(11) Gomes, C.F.S.; Gomes, L.F.A.M. \& Valle, R.A.B. (2002a). One Application of THOR in a Process of Personal Evaluation. The Sixteenth Triennial Conference of the International Federation of Operation Research Societies. IFORS-2002, Edinburgh.

(12) Gomes, C.F.S.; Gomes, L.F.A.M \& Valle, R.A.B. (2002b). One Application THOR (A Multicriteria Decision Aiding Hybrid Algorithm Applied to the Decision Process with Discrete Alternatives). In: 12th Mini-Euro Conference, Bruxelas.

(13) Gomes, L.F.A.M.; Gomes, C.F.S. \& Teixeira, A. (2002c). Tomada de Decisão Gerencial o Enfoque Multicritério. Editora Atlas.

(14) Gomes, C.F.S. (2003). Application of the Multicriteria Decision Making Methodology for Outranking the Ballast Water Management Options - Example and Proposal for Application. In: 5th EURO/IFORMS Joint International Meeting, Abstract Book Euro 2003. Istambul 2003, v.1, p.185.

(15) Haranyi, J.C. (2000). Rational Behaviour and Bargaining Equilibrium in Games and Social Situations. Cambridge Uni. Press, Cambridge.

(16) Karni, E. \& Safra, Z. (2000). An extension of a theorem of Von Neumann and Morgenstern with an application to social choice theory. Journal of Mathematical Economics, 34, 315-327.

(17) Knoblauch, V. (2000). Lexicographic orders and preference representation. Journal of Mathematical Economics, 34.

(18) Mármol, A.M.; Puerto, J. \& Fernández, F.R. (2002). Sequential incorporation of imprecise information in multiple criteria decision processes. European Journal of Operational Research, 137, 123-133.

(19) Matsatsinis, N.F. \& Samaras, A.P. (2001). MCDA and preferences disaggregation in group decision support systems. European Journal of Operational Research, 130, 414-429.

(20) Noussair, C. \& Matheny, K. (2000). An experimental study of decisions in dynamic optimisation problems. Economic Theory, 15, 389-419. Savage, L.J. The Foundation of Statistics. Wiley.

(21) Torgerson, W.S. (1985). Theory and methods of scaling. John Wiley, New York.

(22) Varlan, E. \& Paillier, R.L. (1999). Multicriteria Decision making for contract research organisation choice in the pharmaceutical industry. Journal of the Operation Research Society, 50, 943-948. 
(23) Vind, K. (2000). von Neumann Morgenstern preferences. Journal of Mathematical Economics, 33, 109-122.

(24) Zopounidis, C. \& Doumpos, M. (2002). Multicriteria classification and sorting methods: a literature review. European Journal of Operational Research, 138, 229-246.

(25) Zopounidis, C. \& Doumpos, M. (2003). Developing sorting models using preference disaggregation analysis: an experimental investigation. European Journal of Operational Research.

\section{Annex I - Comparison of alternatives (THOR algorithm)}

Any two alternatives are incomparable in three situations:

Situation $1: * a \mathrm{ab}-\mathrm{bPa} *<\mathrm{F} 1$;

Situation 2: $* \mathrm{aPb}+\mathrm{aQb}-\mathrm{bPa}-\mathrm{bQa} *<\mathrm{F} 2$;

Situation 3: $* \mathrm{aPb}+\mathrm{aQb}-\mathrm{bPa}-\mathrm{bQa} *+\mathrm{F} 3<\mathrm{F} 4$,

Where:

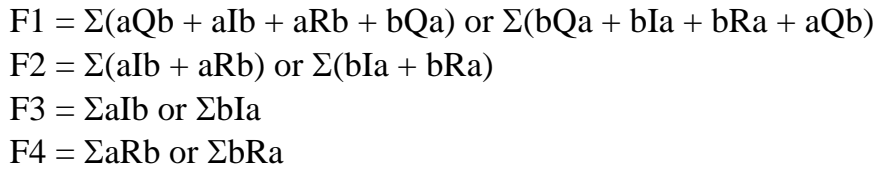

As an example, consider the following alternatives matrix (Table II):

Table II

\begin{tabular}{|l|c|c|c|c|}
\hline Alternatives & $\underline{\mathrm{a}}$ & $\underline{\mathrm{b}}$ & $\underline{\mathrm{c}}$ & Results \\
\hline$\underline{\mathrm{a}}$ & 0.0 & $I$ & 0.6 & 1.1 \\
\hline$\underline{\mathrm{b}}$ & $I$ & 0.0 & 0.6 & 1.1 \\
\hline$\underline{\mathrm{c}}$ & 0.4 & 0.4 & 0.0 & 0.8 \\
\hline
\end{tabular}

Letter I indicates that the alternatives are indifferent $(I=0.5)$. Alternative $\underline{a}$ is indifferent to alternative $\underline{b}$ and it dominates alternative $\underline{c}$ in 0.6 of the sum of the weights of the criteria. In the same way, alternative $\underline{b}$ is indifferent to alternative $\underline{a}$, and it also dominates alternative $\underline{c}$ in 0.6 of the sum of the weights of the criteria. Therefore, alternatives $\underline{a}$ and $\underline{b}$ have the same "score".

In another example, consider the rankings $\mathrm{S}_{1}, \mathrm{~S}_{2}$ and $\mathrm{S}_{3}$ in the following table (Table III):

Table III

\begin{tabular}{|l|c|c|c|c|}
\hline Alternatives & $\underline{\mathrm{a}}$ & $\underline{\mathrm{b}}$ & $\underline{\mathrm{c}}$ & Results \\
\hline$\underline{\mathrm{a}}$ & 0.0 & $I$ & 0.6 & 1.1 \\
\hline$\underline{\mathrm{b}}$ & $I$ & 0.0 & 0.6 & 1.1 \\
\hline$\underline{\mathrm{c}}$ & 0.4 & 0.4 & 0.0 & 0.8 \\
\hline
\end{tabular}


To simplify, we will assume that:

- all four criteria classify the alternatives in a scale from 1 to 7.

- for all the criteria, $q=0.9$ and $\mathrm{p}=1.9$.

- for all the approaches, discordance (D) will be equal to 4 .

- for all the approaches and alternatives, pertinence is equal to 1 .

The notion of discordance is similar to that used in the algorithms of the ELECTRE family and has the same definition (inter-criteria analysis).

It is important to remark that the discordance value (intra-criteria analysis) is a direct result of the judgment of values by the decision-makers, and one should pay close attention to which kind of scale is used to express the values of the criteria weights, as well as to the classification of the alternatives in the criteria.

Comparing $\mathrm{a}_{1}$ with $\mathrm{a}_{2}$, we observe:

$$
\begin{aligned}
& \mathrm{a}_{1} \mathrm{~Pa}_{2}=\mathrm{c}_{1} \text { (weight 6); } \\
& \mathrm{a}_{1} \mathrm{Qa}_{2}=\mathrm{c}_{2} \text { (weight 5); } \\
& \mathrm{a}_{1} \mathrm{Ia}_{2}=\mathrm{c}_{3} \text { (weight 4); } \\
& \mathrm{a}_{2} \mathrm{~Pa}_{1}=\mathrm{c}_{4} \text { (weight 2). }
\end{aligned}
$$

Ranking $\mathrm{S}_{1}$ : $\mathrm{a}_{1}$ will dominate $\mathrm{a}_{2}$, if $\mathrm{a}_{1} \mathrm{~Pa}_{2}>\left(\mathrm{a}_{1} \mathrm{Qa}_{2}+\mathrm{a}_{1} \mathrm{Ia}_{2}+\mathrm{a}_{2} \mathrm{~Pa}_{1}+\mathrm{a}_{2} \mathrm{Qa}_{1}\right)$. Since $6<$ $(5+4+2), a_{1}$ does not dominate $a_{2}$.

$\mathrm{a}_{2}$ will dominate $\mathrm{a}_{1}$, if $\mathrm{a}_{2} \mathrm{~Pa}_{1}>\left(\mathrm{a}_{2} \mathrm{Qa}_{1}+\mathrm{a}_{2} \mathrm{Ia}_{1}+\mathrm{a}_{1} \mathrm{~Pa}_{1}+\mathrm{a}_{1} \mathrm{Qa}_{2}+\mathrm{a}_{2} \mathrm{Ra}_{1}\right)$. Since $2<(4+6+5), a_{2}$ does not dominate $a_{1}$. Therefore, $a_{1}$ and $a_{2}$ are indifferent for the decision-maker.

Ranking $\mathrm{S}_{2}$ : $\mathrm{a}_{1}$ will dominate $\mathrm{a}_{2}$, if $\left(\mathrm{a}_{1} \mathrm{~Pa}_{2}+\mathrm{a}_{1} \mathrm{Qa}_{2}\right)>\left(\mathrm{a}_{1} \mathrm{Ia}_{2}+\mathrm{a}_{2} \mathrm{~Pa}_{1}+\mathrm{a}_{2} \mathrm{Q} \mathrm{a}_{1}+\mathrm{a}_{1} \mathrm{Ra}_{2}\right)$. Since $(6+5)>(4+2), a_{1}$ dominates $a_{2}$. In the approach $c_{4}$, where the dominated alternative $a_{2}$ overcomes $a_{1}$, if $a_{2}$ dominates $a_{1}(7-2=5)$ with a difference greater than or equal to the discordance, then the dominance of $\mathrm{a}_{1}$ ceases and these two alternatives are again indiscernible. On the other hand, $a_{2}$ will dominate $\mathrm{a}_{1}$, if $\left(\mathrm{a}_{2} \mathrm{~Pa}_{1}+\mathrm{a}_{2} \mathrm{Qa}_{1}\right)>\left(\mathrm{a}_{1} \mathrm{Ia}_{2}+\mathrm{a}_{1} \mathrm{~Pa}_{2}+\mathrm{a}_{1} \mathrm{Qa}_{2}+\mathrm{a}_{1} \mathrm{Ra}_{2}\right)$. Since $2<$ $(6+5+4), a_{2}$ does not dominate $\mathrm{a}_{1}$, and $\mathrm{a}_{1}$ and $\mathrm{a}_{2}$ are indiscernible to the decision-maker.

Ranking $\mathrm{S}_{3}: \quad \mathrm{a}_{1}$ will dominate $\mathrm{a}_{2}$, if $\left(\mathrm{a}_{1} \mathrm{~Pa}_{2}+\mathrm{a}_{1} \mathrm{Qa}_{2}+\mathrm{a}_{1} \mathrm{Ia}_{2}\right)>\left(\mathrm{a}_{2} \mathrm{~Pa}_{1}+\mathrm{a}_{2} \mathrm{Qa}_{1}+\mathrm{a}_{1} \mathrm{Ra}_{2}\right)$. Since $(6+5+4)>2, \mathrm{a}_{1}$ dominates $\mathrm{a}_{2}$. In the approach $\mathrm{c}_{4}$, where the dominated alternative $a_{2}$ overcame $a_{1}$, if $a_{2}$ overcomes $a_{1}(7-2=5)$ with difference greater than or equal to the discordance, then the dominance of $\mathrm{a}_{1}$ ceases and these two alternatives are again indiscernible. On the other hand, $\mathrm{a}_{2}$ will dominate $\mathrm{a}_{1}$, if $\left(\mathrm{a}_{2} \mathrm{~Pa}_{1}+\mathrm{a}_{2} \mathrm{Qa}_{1}+\mathrm{a}_{1} \mathrm{Ia}_{2}\right)>\left(\mathrm{a}_{1} \mathrm{~Pa}_{2}+\mathrm{a}_{1} \mathrm{Qa}_{2}+\mathrm{a}_{1} \mathrm{Ra}_{2}\right)$. Since $(2+4)$ $<(6+5), a_{2}$ does not dominate $\mathrm{a}_{1}$, and $\mathrm{a}_{1}$ and $\mathrm{a}_{2}$ are indiscernible.

Comparing $\mathrm{a}_{1}$ with $\mathrm{a}_{3}$ :

$$
\begin{aligned}
& \left.\mathrm{a}_{1} \mathrm{~Pa}_{3}=\mathrm{c}_{1} \text { (I weight } 6\right) . \\
& \left.\left.\mathrm{a}_{1} \mathrm{Ia}_{3}=\mathrm{c}_{2} \text { (I weight } 5\right), \mathrm{c}_{3} \text { (I weight } 4\right) . \\
& \left.\mathrm{a}_{1} \mathrm{Qa}_{3}=\mathrm{c}_{4} \text { (I weight } 2\right) .
\end{aligned}
$$


Ranking $\mathrm{S}_{1}$ : For $\mathrm{a}_{1}$ to dominate $\mathrm{a}_{3}$, it is necessary for $\mathrm{a}_{1} \mathrm{~Pa}_{3}>\left(\mathrm{a}_{1} \mathrm{Qa}_{3}+\mathrm{a}_{1} \mathrm{Ia}_{3}+\mathrm{a}_{3} \mathrm{~Pa}_{1}+\mathrm{a}_{3} \mathrm{Qa}_{1}\right.$ $\left.+a_{1} R a_{2}\right)$. Since $6<(5+4+2)$, then $a_{1}$ does not dominate $a_{3}$. For $a_{3}$ to dominate $\mathrm{a}_{1}$, it is necessary for $\mathrm{a}_{3} \mathrm{~Pa}_{1}>\left(\mathrm{a}_{3} \mathrm{Qa}_{1}+\mathrm{a}_{3} \mathrm{Ia}_{1}+\mathrm{a}_{3} \mathrm{~Pa}_{1}+\mathrm{a}_{3} \mathrm{Qa}_{1}+\mathrm{a}_{3} \mathrm{Ra}_{1}\right)$. Since 0 is not $>(6+5+4+2), a_{3}$ does not dominate $a_{1}$, so, for the ranking $S 1$, $\mathrm{a}_{1}$ and $\mathrm{a}_{3}$ "are equivalent" for the decision-maker.

Ranking $\mathrm{S}_{2}$ : For $\mathrm{a}_{1}$ to dominate $\mathrm{a}_{3}$, it is necessary for $\left(\mathrm{a}_{1} \mathrm{~Pa}_{3}+\mathrm{a}_{1} \mathrm{Qa}_{3}\right)>\left(\mathrm{a}_{1} \mathrm{Ia}_{3}+\mathrm{a}_{3} \mathrm{~Pa}_{1}+\right.$ $\left.\mathrm{a}_{3} \mathrm{Qa}_{1}+\mathrm{a}_{1} \mathrm{Ra}_{3}\right)$. Since $(6+2)$ is not bigger than $(5+4)$, $\mathrm{a}_{1}$ does not dominate $a_{3}$. For $a_{3}$ to dominate $a_{1}$ it is necessary for $\left(a_{3} \mathrm{~Pa}_{1}+\mathrm{a}_{3} \mathrm{Qa}_{1}\right)>\left(\mathrm{a}_{1} \mathrm{Ia}_{3}+\mathrm{a}_{1} \mathrm{~Pa}_{3}+\right.$ $\left.\mathrm{a}_{1} \mathrm{Qa}_{3}+\mathrm{a}_{1} \mathrm{Ra}_{2}\right)$. Since 0 is not $>(6+5+4+2)$, $\mathrm{a}_{3}$ does not dominate $\mathrm{a}_{1}$, and it is so confirmed that $\mathrm{a}_{1}$ and $\mathrm{a}_{2}$ are indiscernible for the decision-maker.

Ranking $\mathrm{S}_{3}$ : For $\mathrm{a}_{1}$ to dominate $\mathrm{a}_{3}$, it is necessary for $\left(\mathrm{a}_{1} \mathrm{~Pa}_{3}+\mathrm{a}_{1} \mathrm{Qa}_{3}+\mathrm{a}_{1} \mathrm{Ia}_{3}\right)>\left(\mathrm{a}_{3} \mathrm{~Pa}_{1}+\right.$ $\left.\mathrm{a}_{3} \mathrm{Qa}_{1}+\mathrm{a}_{1} \mathrm{Ra}_{2}\right)$. Since $(6+5+4+2)$ is bigger than $0, \mathrm{a}_{1}$ dominates $\mathrm{a}_{3}$. For $\mathrm{a}_{3}$ to dominate $\mathrm{a}_{1}$, it will be necessary for $\left(\mathrm{a}_{3} \mathrm{~Pa}_{1}+\mathrm{a}_{3} \mathrm{Qa}_{1}+\mathrm{a}_{1} \mathrm{Ia}_{3}\right)>\left(\mathrm{a}_{1} \mathrm{~Pa}_{3}+\mathrm{a}_{1} \mathrm{Qa}_{3}+\right.$ $\left.a_{1} R_{3}\right)$. Since $(5+4)>(6+2), a_{3}$ dominates $a_{1}$. As $a_{1}$ dominates $a_{3}$, $a_{3}$ will receive the same score [sum of the weights of the approaches in which $\mathrm{a}_{1}$ dominates $\mathrm{a}_{3}$ ] divided by the [sums of the weights of the approaches], that in this situation the value is 1 . Since $a_{3}$ also dominates $a_{1}$, it will receive 9 divided by 17 that it is the same to 0.52 .

Comparing $\mathrm{a}_{2}$ with $\mathrm{a}_{3}$ :

$$
\begin{aligned}
& \left.\mathrm{a}_{2} \mathrm{~Pa}_{3}=\mathrm{c}_{4} \text { (I weight } 2\right) . \\
& \left.\left.\mathrm{a}_{2} \mathrm{Ia}_{3}=\mathrm{c}_{1} \text { (I weight } 6\right) \text { and } \mathrm{c}_{3} \text { (I weight } 4\right) . \\
& \mathrm{a}_{3} \mathrm{Qa}_{2}=\mathrm{c}_{2} \text { (I weight } 5 \text { ). }
\end{aligned}
$$

Ranking $\mathrm{S}_{1}$ : For $\mathrm{a}_{2}$ to dominate $\mathrm{a}_{3}$, it is necessary for $\left(\mathrm{a}_{2} \mathrm{~Pa}_{3}\right)>\left(\mathrm{a}_{2} \mathrm{Qa}_{3}+\mathrm{a}_{2} \mathrm{Ia}_{3}+\mathrm{a}_{3} \mathrm{~Pa}_{2}+\right.$ $\left.\mathrm{a}_{3} \mathrm{Qa}_{2}+\mathrm{a}_{3} \mathrm{Ra}_{2}\right)$. Since 2 is not bigger $(6+5+4), \mathrm{a}_{2}$ does not dominate $\mathrm{a}_{3}$. For $\mathrm{a}_{3}$ to dominate $\mathrm{a}_{2}$ it will be necessary for $\left(\mathrm{a}_{3} \mathrm{~Pa}_{2}\right)>\left(\mathrm{a}_{3} \mathrm{Qa}_{2}+\mathrm{a}_{3} \mathrm{Ia}_{2}+\mathrm{a}_{3} \mathrm{~Pa}_{2}+\right.$ $\left.\mathrm{a}_{3} \mathrm{Qa}_{2}+\mathrm{a}_{3} \mathrm{Ra}_{2}\right)$. As 0 is not bigger than $(6+5+4+2), \mathrm{a}_{3}$ does not dominate $\mathrm{a}_{2}$, so for the ranking $\mathrm{S} 1, \mathrm{a}_{2}$ and $\mathrm{a}_{3}$ are "equivalent" for the decision-maker.

Ranking $\mathrm{S}_{2}$ : For $\mathrm{a}_{2}$ to dominate $\mathrm{a}_{3}$, it is necessary for $\left(\mathrm{a}_{2} \mathrm{~Pa}_{3}+\mathrm{a}_{2} \mathrm{Qa}_{3}\right)>\left(\mathrm{a}_{2} \mathrm{Ia}_{3}+\mathrm{a}_{3} \mathrm{~Pa}_{2}+\right.$ $\left.\mathrm{a}_{3} \mathrm{Qa}_{2}+\mathrm{a}_{2} \mathrm{Ra}_{3}\right)$. As 2 is not bigger than $5+6+4, \mathrm{a}_{2}$ does not dominate $\mathrm{a}_{3}$. For $\mathrm{a}_{3}$ to dominate $\mathrm{a}_{2}$, it is necessary for $\left(\mathrm{a}_{3} \mathrm{~Pa}_{2}+\mathrm{a}_{3} \mathrm{Qa}_{2}\right)>\left(\mathrm{a}_{2} \mathrm{Ia}_{3}+\mathrm{a}_{2} \mathrm{~Pa}_{3}+\mathrm{a}_{2} \mathrm{Qa}_{3}+\right.$ $\left.a_{2} R_{3}\right)$. As 5 is not bigger than $(6+4+2), a_{3}$ does not dominate $a_{2}$, and it is confirmed that $\mathrm{a}_{3}$ and $\mathrm{a}_{2}$ are indiscernible for the decision-maker.

Ranking $\mathrm{S}_{3}$ : For $\mathrm{a}_{2}$ to dominate $\mathrm{a}_{3}$, it is necessary for $\left(\mathrm{a}_{2} \mathrm{~Pa}_{3}+\mathrm{a}_{2} \mathrm{Qa}_{3}+\mathrm{a}_{2} \mathrm{Ia}_{3}\right)>\left(\mathrm{a}_{3} \mathrm{~Pa}_{2}+\right.$ $\left.\mathrm{a}_{3} \mathrm{Qa}_{2}+\mathrm{a}_{2} \mathrm{Ra}_{3}\right)$. As $(2+6+4)>5, \mathrm{a}_{2}$ dominates $\mathrm{a}_{3}$, and as the only approach in which $a_{3}$ dominates $a_{2}$ the classification difference $(4-3=1)$ is smaller than the value of the disagreement, so $a_{2}$ really dominates $a_{3}$. For $a_{3}$ to dominate $a_{2}$ it is necessary for $\left(\mathrm{a}_{3} \mathrm{~Pa}_{2}+\mathrm{a}_{3} \mathrm{Qa}_{2}+\mathrm{a}_{2} \mathrm{Ia}_{3}\right)>\left(\mathrm{a}_{2} \mathrm{~Pa}_{3}+\mathrm{a}_{2} \mathrm{Qa}_{3}+\mathrm{a}_{2} \mathrm{Ra}_{3}\right)$. As $(5+6$ $+4)>4, a_{3}$ dominates $a_{2}$. Since $a_{3}$ dominates $a_{2}$, even in the approach $c_{4}$ in which the dominated alternative $a_{2}$ overcomes $a_{3}, a_{2}$ overcomes $a_{3}(7-2=5)$ for a larger difference than the disagreement, with this the dominance of $a_{3}$ ceases and these are indiscernible for the decision-maker again. If the dominance was considered without the disagreement $\mathrm{a}_{2}$ it receives the score of $[2+4+6]$ divided by 17 , i.e., 0.706 , and $\mathrm{a}_{3}$ receives the score $[5+6+4]$ divided by 17 , i.e., 0.882 , as for the score $\mathrm{a}_{3}$ if it receives a larger value than $\mathrm{a}_{2}$, the use of the disagreement equals the alternatives. 


\section{Decision Matrices:}

Table IV - Decision matrix for ranking $\mathrm{S}_{1}$.

\begin{tabular}{|l|c|c|c|c|}
\hline & $\mathrm{a}_{1}$ & $\mathrm{a}_{2}$ & $\mathrm{a}_{3}$ & Score \\
\hline $\mathrm{a}_{1}$ & 0 & $I$ & $I$ & 1.00 \\
\hline $\mathrm{a}_{2}$ & $I$ & 0 & $I$ & 1.00 \\
\hline $\mathrm{a}_{3}$ & $I$ & $I$ & 0 & 1.00 \\
\hline
\end{tabular}

Table V - Decision matrix for ranking $\mathrm{S}_{2}$.

\begin{tabular}{|c|c|c|c|c|}
\hline & $\mathrm{a}_{1}$ & $\mathrm{a}_{2}$ & $\mathrm{a}_{3}$ & Score \\
\hline $\mathrm{a}_{1}$ & 0 & $\mathrm{I}$ & $\mathrm{I}$ & 1.00 \\
\hline $\mathrm{a}_{2}$ & $I$ & 0 & $I$ & 1.00 \\
\hline $\mathrm{a}_{3}$ & $I$ & $I$ & 0 & 1.00 \\
\hline
\end{tabular}

Table VI - Decision matrix for ranking $S_{3}$.

\begin{tabular}{|c|c|c|c|c|}
\hline & $\mathrm{a}_{1}$ & $\mathrm{a}_{2}$ & $\mathrm{a}_{3}$ & Score \\
\hline $\mathrm{a}_{1}$ & 0 & $I$ & 1.00 & 1.50 \\
\hline $\mathrm{a}_{2}$ & $I$ & 0 & $I$ & 1.00 \\
\hline $\mathrm{a}_{3}$ & 0.52 & $I$ & 0 & 1.02 \\
\hline
\end{tabular}

Only the ranking $\mathrm{S}_{3}$ allows a separation among the alternatives. 